Jurnal Geocelebes Vol. 1 No. 2, Oktober 2017, 62 - 65

\title{
KARAKTERISTIK FISIK DAN KIMIA MATAAIR PANAS DAERAH BARASANGA KABUPATEN KONAWE UTARA, PROVINSI SULAWESI TENGGARA
}

\author{
Jamaluddin $^{1 *}$, Emi Prasetyawati Umar ${ }^{2}$ \\ ${ }^{1}$ Jurusan Teknik Geologi, Sekolah Geosains, China University of Petroleum, Qingdao, China \\ ${ }^{2}$ Jurusan Teknik Pertambangan, Fakultas Teknologi Industri , Universitas Muslim Indonesia, Makassar, \\ Indonesia
}

*Penulis koresponden. Alamat email: jamaljamaluddin1994@gmail.com

\begin{abstract}
Abstrak
Daerah Barasanga menunjukkan manifestasi panasbumi berupa mataair panas dan endapan travertin. Penelitian ini bertujuan menganalisis karakteristik fisik dan kimia mataair panas Barasanga. Metode yang digunakan adalah studi pustaka dan observasi lapangan seperti pemetaan sebaran mataair panas, pengambilan sampel batuan kemudian dianalisis laboratorium. Hasil penelitian menunjukkan bahwa tipe dan jenis travertin pada mataair panas di daerah penelitian termasuk ke dalam jenis Incoherent Travertines. Suhu rata-rata $48{ }^{\circ} \mathrm{C}$ dan $\mathrm{pH} 7,85$, warna jernih, berbau belerang dan berasa asin. Geokimia tipe mataair panas daerah penelitian merupakan tipe air klorida.
\end{abstract}

Kata kunci: Barasanga, Manifestasi, Mataair panas, Panasbumi, Travertin

\begin{abstract}
Barasanga determined the manifestation of geothermal of hot water spring and sediment of travertine. This research aimed to analyze physical and chemistry characteristics of hot springs in Barasanga . The methods used are literature study and field observations such as mapping the distribution of hot water spring, rock samples were analyzed in the laboratory. The results showed that the type and variety of travertine in the hot water Spring in the research area were classified as Incoherent Travertines. Average temperature of $48{ }^{\circ} \mathrm{C}$ and $\mathrm{pH}$ of 7.85 , clear color, smelled sulfur and taste the salty. Geochemical types of hot water Spring is a type of chloride.
\end{abstract}

Key Words : Barasanga, Manifestation, Hot water Spring, Geothermal, Travertin

\section{Pendahuluan}

Pulau Sulawesi memiliki potensi energi alternatif berupa panasbumi (geothermal) akibat adanya proses geologi berupa vulkanisme dan tektonik. Manifestasi panasbumi di permukaan terjadi karena adanya rekahan yang memungkinkan fluida panas ke permukaan, rekahan dapat terbentuk karena adanya struktur geologi yaitu sesar Lasolo yang terdapat di Daerah
Barasanga. Sesar Lasolo diperkirakan masih aktif hingga sekarang yang ditandai dengan keterdapatan mataair panas di daerah Barasanga (Rusmana, dkk. 1993).

Berdasarkan survey lapangan daerah Barasanga menunjukkan karakteristik panasbumi berupa manifestasi yaitu mataair panas dan akumulasi pengendapan mineral kalsit atau mineral karbonat $\left(\mathrm{CaCO}_{3}\right)$ yang membentuk travertin. 
Travertin merupakan bagian dari batuan sedimen karbonat terestrial atau darat yang dibentuk oleh pengendapan atau prespitasi mineral karbonat dari larutan dalam tanah dan permukaan air, dan atau secara pemanasan dari mataair panas (Pentecost, 2005). Mataair panas dianalisis secara fisik dan kimia melalui pendekatan geokimia untuk mengetahui tipe mataair panas daerah Barasanga.

\section{Geologi Regional}

Secara regional, struktur dan geologi yang dijumpai pada peta geologi Lembar Lasusua-Kendari (gambar 1) adalah Sesar, Lipatan dan Kekar. Sesar dan kelurusan umumnya berarah Baratlaut-Tenggara searah dengan sesar Lasolo. Sesar Lasolo berupa sesar geser jurus mengiri (sinistral) yang diduga masih giat hingga kini, yang dibuktikan dengan adanya mata air panas di Batugamping terumbu yang berumur Jolosen pada Jalur Sesar tersebut di Tenggara Tinobu, tepatnya di daerah Barasanga Kecamatan Lasolo. Sesar naik ditemukan di Tanjung Labuandala di selatan Lasolo, yaitu beranjaknya batuan ofiolit ke atas batuan Formasi Meluhu. Sesar Lasolo berarah Baratlaut-Tenggara, membagi Lembar Kendari menjadi dua bagian. Sebelah timurlaut sesar disebut Lajur Hialu dan sebelah baratdaya disebut Lajur Tinondo (Rusmana, dkk, 1993). Lajur Hialu umumnya merupakan himpunan batuan yang bercirikan asal Kerak Samudera dan Lajur Tinondo merupakan himpunan batuan yang bercirikan asal paparan benua.

\section{Komposisi Kimia Mataair Panas}

Pada saat air tanah bersentuhan dengan mineral yang ada dalam tanah dan batuan, maka terjadilah pelarutan mineral-mineral tersebut. Proses ini berlanjut hingga tercapai kesetimbangan konsentrasi unsurunsur dalam air tanah. Dalam sistem mataair panas, rata-rata nilai $\mathrm{pH}$ adalah asam sampai basa (4-9) dimana $\mathrm{pH}$ pada air permukaan lebih besar daripada air di kedalaman. Dari nilai $\mathrm{pH}$ ini dapat mengindikasikan adanya jenis air yang terkandung dalam suatu sistem panasbumi. Dimana jenis air ini tergantung dari unsurunsur kimia yang terkandung di dalamnya. Pada kedalaman kurang dari $2 \mathrm{~km}$, dengan adanya peningkatan permeabilitas batuan, fluida reservoir akan mendidih yang mengakibatkan tingginya konsentrasi unsur-unsur yang tidak dapat menguap, sedangkan unsur yang mudah menguap larut kedalam air mengakibatkan $\mathrm{pH}$ semakin asam.

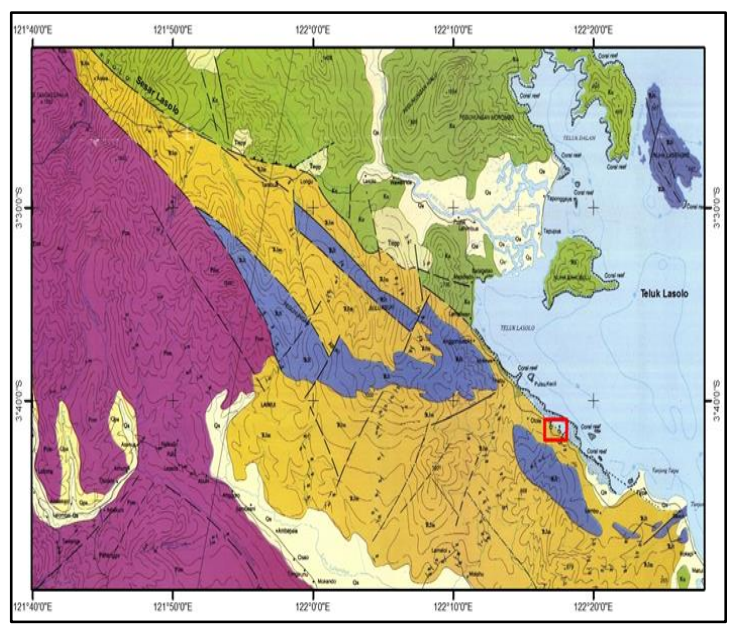

Gambar 1. peta geologi Lembar Lasusua-Kendari

\section{Karakteristik Mataair Panas}

Keberadaan mataair panas pada suatu daerah, dapat terbentuk oleh dua sebab yaitu oleh aktivitas tektonik aktif dan vulkanisme (Nicholson, 1993):

a) Mataair panas akibat vulkanik aktif, dicirikan oleh air panas dengan temperatur permukaan yang tinggi dengan suhu di atas $100^{\circ} \mathrm{C}$, suhunya tetap, dijumpai endapan sinter, sulfat dan sulfur, memiliki kandungan ion sulfat dan unsur sulfur yang tinggi akibat reaksi oksidasi $\mathrm{H}_{2} \mathrm{~S}$ di atas permukaan tanah dan unsur volatil magma dari kegiatan vulkanik.

b) Mataair panas akibat tektonik aktif, dicirikan oleh air panas temperatur permukaan rendah dengan suhu antara $20^{\circ}-100^{\circ} \mathrm{C}$, dijumpai berupa travertin, dan memiliki kandungan ion sulfat dan unsur sulfur yang relatif lebih rendah. 


\section{Metode Penelitian}

Penelitian ini menggunakan pendekatan metode kualitatif dan kuantitatif yang dipadukan dengan hasil kajian pustaka, penelitian terdahulu, data lapangan, serta hasil penelitian laboratorium yang keseluruhannya dikaji dan dianalisis. Analisis sifat fisik dan kimia mataair panas melalui analisis kimia air panas dengan menggunakan diagram trilinier dalam penentuan tipe mataair panas daerah Barasanga melalui pendekatan geokimia.

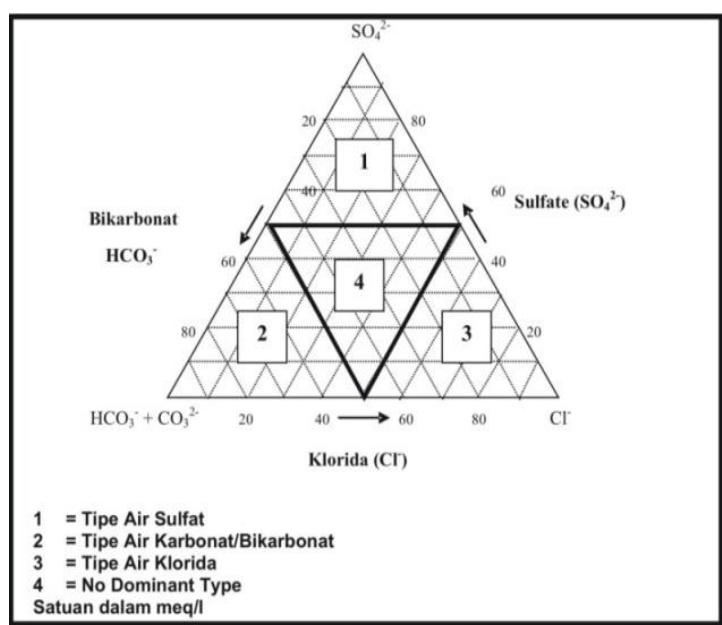

Gambar 2. Diagram Trilinier untuk penentuan tipe mataair panas berdasarkan kandungan ion klorida, sulfat dan bikarbonat (Nicholson, 1993).

\section{Hasil dan Pembahasan}

Daerah penelitian, tepatnya daerah tempat keluarnya mata air panas tersusun oleh litologi berupa batugamping, dimana mataair panas keluar melalui rekahanrekahan pada batugamping tersebut.

Tabel 1 menunjukkan sifat fisik mataair panas berupa warna, bau, rasa, suhu, dan $\mathrm{pH}$ dari keenam sampel mataair panas. Dari tabel tersebut terlihat jelas bahwa nilai rata-rata kandungan $\mathrm{pH}$ dari keenam mataair panas berkisar antara 7,85 dan memiliki rasa asin, bau belerang (sulfur) karena dari hasil analisis kimia kandungan sulfur dari keenam mataair panas rata-rata $10,3 \%$ sehingga menyebabkan terciumnya bau belerang di sekitar daerah manifestasi panasbumi namun kandungan dari belerang ini terlampau kecil dari kandungan belerang dari sistem panasbumi dari daerah vulkanik. Kenampakan warna mataair panas disalah satu stasiun pengamatan dapat dilihat pada gambar 3 .

Rasa asin dari mataair panas didukung oleh hasil analisis kimia mataair panas yang mengandung kadar salinitas sebesar $20 \%$, hal ini terjadi karena daerah terdapatnya mataair panas berdekatan dengan daerah laut, ditunjukkan juga dengan nilai Klorida $(\mathrm{Cl})$ yang tinggi yang menyebabkan terjadinya reaksi Natrium (Na) yang dikandung mataair panas dengan ion klorida sehingga menimbulkan rasa asin dari mataair panas yang berpengaruh terhadap nilai $\mathrm{pH}$ dari keenam sampel mataair panas yaitu ratarata $7,8-7,9$.

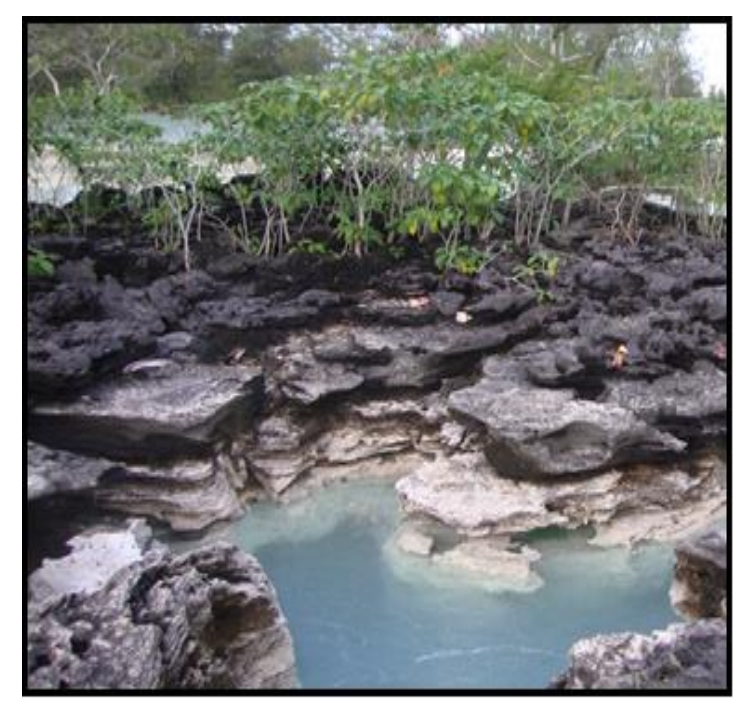

Gambar 3. Kenampakan warna mataair panas.

Fluida reservoar umumnya berasal dari air meteorik yang meresap kedalam tanah. Reaksi fluida dengan batuan reservoar sangat berpengaruh dalam merubah komposisi air yang masuk ke dalam reservoar. Nilai $\mathrm{pH}$ yang didapatkan dari sampel mataair panas tersebut dapat mengindikasikan adanya jenis air yang terkandung dalam suatu sistem panasbumi. Jenis air tersebut ini tergantung dari unsurunsur kimia yang terkandung di dalamnya. 
Tabel 1. Tabel ciri fisik dan kimia mataair panas daerah penelitian.

\begin{tabular}{llcccccc}
\hline NO & \multirow{2}{*}{ Parameter } & \multicolumn{6}{c}{ Mataair Panas (MAP) } \\
\cline { 3 - 8 } & & I & II & III & IV & V & VI \\
\hline 1 & Warna & Jernih & Jernih & Jernih & Jernih & Jernih & Jernih \\
\hline 2 & Bau & Sulfur & Sulfur & Sulfur & Sulfur & Sulfur & Sulfur \\
\hline 3 & Rasa & Asin & Asin & Asin & Asin & Asin & Asin \\
\hline 4 & Suhu $\left({ }^{\circ} \mathrm{C}\right)$ & 50 & 40 & 50 & 53 & 51 & 45 \\
\hline 5 & pH & 7,9 & 7,9 & 7,8 & 7,8 & 7,8 & 7,9 \\
\hline
\end{tabular}

Hasil pengukuran suhu dari mata air panas I dan III memiliki suhu yaitu $50^{\circ} \mathrm{C}$ sedangkan pada mataair panas IV dan $\mathrm{V}$ yaitu $53^{\circ} \mathrm{C}$ dan $51^{\circ} \mathrm{C}$. Pada mataair panas VI dan II agak sedikit lebih rendah yaitu $45^{\circ} \mathrm{C}$ dan $40^{\circ} \mathrm{C}$. Rata-rata suhu permukaan mataair panas pada daerah Barasanga menunjukkan suhu yang kurang dari $100^{\circ} \mathrm{C}$. Hal tersebut menunjukkan karakteristik kimia air panas yang sama dengan kimia air tanah di sekitarnya. Dengan temperatur permukaan dari keenam mata air panas yang berkisar antara $40^{\circ} \mathrm{C}-53^{\circ} \mathrm{C}$ pada daerah penelitian maka termasuk kedalam temperatur rendah yang merupakan penciri dari mata air panas dari daerah non vulkanik yang memungkinkan air tanah bekerja secara langsung untuk dipanaskan.

Keberadaan manifestasi panasbumi dipermukaan, diperkirakan terjadi karena adanya perambatan panas dari permukaan atau karena adanya rekahan-rekahan yang memungkinkan fluida panasbumi mengalir ke permukaan (Gupta, dkk 2007). Nilai rata-rata kandungan $\mathrm{pH}$ mataair panas berkisar antara 7,85 dan memiliki rasa asin, bau belerang (sulfur), kenampakan warna mataair panas yang terlihat begitu jernih. Sedangkan temperatur permukaan dari mata air panas yang berkisar antara 40 ${ }^{\circ} \mathrm{C}$ pada daerah penelitian maka termasuk kedalam Low Temperature Water yang merupakan penciri dari mata air panas akibat proses tektonik (Brophy, 2011).

\section{Kesimpulan}

Sifat fisik mataair panas yaitu memiliki suhu rata-rata $48^{\circ} \mathrm{C}$ dan $\mathrm{pH} 7,85$, dengan warna jernih, berbau belerang dan berasa asin sedangkan dari hasil geokimia tipe mataair pada daerah penelitian tersebut adalah tipe air klorida (chloride water).

\section{Daftar Pustaka}

Brophy, P. (2011). An Introduction to Geothermal Energy,. USA: CGEC Geothermal Outreach Workshop.

Grupta, H. and Roy, S. (2007). Geothermal Energy. Amsterdam, Netherland: Elsevier.

Nicholson, K. (1993). Geothermal Fluids Chemistry and Exploration Technique. Scotlandia, UK: School of Applied Science, University Aberden.

Pentecost, A. (2005). Travertine Dordrecht Netherlands. Kluwer Academic Publisher Group.

Rusmana, E., Sukido, Sukarna, D., Haryono, E., Simanjuntak, T.O. (1993). Keterangan Peta Geologi Lembar Lasusua - Kendari, Sulawesi, Skala 1:250.000. Bandung: Puslitbang Geologi, Badan Geologi. 